\title{
Interbank Networks in the Shadows of the Federal Reserve Act*
}

Haelim Anderson ${ }^{\dagger}$

\author{
Selman Erol ${ }^{\ddagger}$
}

February 15, 2019

\begin{abstract}
Central banks provide public liquidity (through lending facilities and promises of bailouts) with the intent to stabilize financial markets. Even though this provision is restricted to member (regulated) banks, an interbank system can in principle develop so to give indirect access to nonmember (shadow) banks. We construct a model to understand how the network may change in the presence of Central Bank interventions and how those changes can translate into more room for contagion and an endogenously higher financial fragility. We provide evidence that upon the introduction of the Fed's lending facilities in 1914, aggregate liquidity declined and systemic risks increased.
\end{abstract}

\section{Introduction}

Since the global financial crisis of 2007-2009, the lack of unregulated (shadow) banks' access to the Fed's traditional lending facilities and its impact to financial stability has been a recurrent policy discussion. Should have the Fed extended these facilities to non-member banks? Was the right policy to use emergency lending programs to provide liquidity to shadow banks during the crisis? What is the effect of monetary policy based on Fed funds interest rates on the shadow banking sector and the stability of the financial system?

These questions are not new, and were prominent during the initial phases of the Federal Reserve Bank, founded in 1913 to provide liquidity to the banking system by offering only

\footnotetext{
*PRELIMINARY. PLEASE DO NOT CITE WITHOUT PERMISSION.

${ }^{\dagger}$ Federal Deposit Insurance Corporation. email: handerson@fdic.gov

${ }^{\ddagger}$ Carnegie-Mellon University Tepper School of Business. email: erol@cmu.edu

$\S$ University of Pennsylvania and NBER. email: ordonez@econ.upenn.edu
} 
member banks access to discount window lending. Most state banks, however, chose not to become members, but instead relied on Federal Reserve liquidity provision through indirect pass-throughs of discount window borrowing from their member correspondent banks. The Federal Reserve Act created a system of shadow banks that operated without direct access to central bank liquidity and hence without the same level of supervisory requirements.

We claim that part of the reason was that some banks considered more beneficial to access the Fed's liquidity provision indirectly through an interbank network instead of facing regulatory costs related to becoming a member of the system to obtain those funds directly. Having a large number of banks outside the realm of the Federal Reserve System may constrain the Fed's ability to implement monetary policy, to affect the likelihood of crises and to steer the system during a recovery. This discussion indeed was revived during the Great Depression, leading to the creation of a new lending facility called the Reconstruction Finance Corporation (Anbil and Vossmeyer (2017)).

In spite of the useful information provided by the experience of the initial years of the Federal Reserve System, limited studies have been conducted to investigate how the founding of the Federal Reserve Act changed the nature of the interbank system and affected the stability of the banking system. Among those studies, some examine the effect of Federal Reserve liquidity provision on seasonal liquidity pressures on the banking system, while others focus on the structure of interbank networks and the implication for systemic risk during the Great Depression (see Mitchener and Richardson (2016); Carlson and Wheelock (2018)). In this paper, we exploit the unique event of the Fed's introduction to examine how the provision of public liquidity changed the nature of the interbank system and affected the stability of the banking system.

We construct various datasets for this study. First, we construct state-level balance sheet information for state and national banks from 1910 to 1929. The balance sheets were collected on the last day of June in each year. By using state-level aggregate balance sheet information, we examine the impact of the Federal Reserve Act on the U.S. banking system. Then, we augment this data with bank-level balance sheet information for state banks, which allows us to distinguish more precisely between members and nonmembers, alleviating potential concerns that some of the patterns are driven by state banks that become members after the introduction of the Fed.

We find that the introduction of the Federal Reserve System reduced the aggregate liquidity held by the banking system. For member banks, the proportion of assets held as cash assets and correspondent deposits decreased significantly after the creation of the Fed, which can be easily attributed to a reduction in reserve requirements under the Federal Reserve Act and 
the explicit access to public liquidity. More surprisingly, however, nonmember banks also reduced liquid assets (both cash in vault and deposits held in other banks) even though they were unaffected by changes in reserve requirements. This result is consistent with a more heavy reliance on interbank relations to gain access to public liquidity.

We also find a substantial increase on banking short-term borrowing, both for member and non-member banks, between the Fed?s founding in 1914 and 1920 . While member banks increased short-term borrowing from the Fed, non-member banks did the same from member banks. Nonmember banks? reliance on member banks in financial centers for liquidity made the banking system fragile since they would withdraw interbank deposits if they cannot borrow from their city correspondents.

How these changes affected the risk of contagion and systemic risk in the banking system? To answer this question we need a model to (i) understand how participation and the interbank network is expected to change upon public liquidity provision and (ii) isolate the main forces behind the possibilities of contagion and the direction of such contagion. We propose a model in which banks in a reserve city (such as was the case of New York) have access to investment projects. These banks collect deposits from country banks and pay interest in return. Accordingly, the core is composed by banks with projects while the periphery is composed by banks with liquidity. This characterization is consistent with the fact that, during periods surrounding the Great Depression, the core-periphery used to be in-core (in contrast to modern days in which the financial system is out-core, with the core funding the periphery).

Our study suggests that the founding of the Fed may have created a new source of contagion for the banking system. This is because of the combination of two factors. The first factor is a decline in the liquidity in the banking system due to reliance on central bank liquidity assistance and the reduction in reserve requirements. Financial center banks, in particular, became much less liquid than before even though they faced large deposit withdrawal risk by nonmember banks (to which more short borrowing were channeled). That liquidity declined even for non-member banks suggests that the main channel of the aggregate decline in liquidity can be attributed more to the new reliance on public liquidity rather than to the reduction on reserve requirements, only applicable to member banks.

The second factor is the increased interbank lending activity between city correspondents and country nonmember banks. The founding of the Fed led to the increase in the size of the interbank lending because nonmember banks increased short-term borrowing from their correspondents. The Fed's ability to provide liquidity has a large implication for financial stability since the lack of aggregate liquidity could lead to a reduction in short-term lending 
from city correspondents to nonmember banks. Insufficient short-term lending from city correspondents to nonmember banks would result in the withdrawal of interbank deposits by nonmember banks and financial contagion.

Our findings have important implications for policy today. The presumption that providing public liquidity to (traditional) banking fence off members from potential risks that arise from banks that are not subject to the Fed's oversight seems naï¿œve. Banks that are not subject to regulatory constraints can access such liquidity indirectly through interbank operations. Should the Fed provide liquidity more broadly and introduce restrictions on interbank operations? Potentially this would solve the problem of contagion at the cost of implementing inefficient allocations and insurance. Should the Fed extend the provision of liquidity to other banks without regulating them? What is the social cost of such extension of direct access to liquidity? Our empirical finding and theoretical framework helps putting discipline to these questions.

Our paper makes contributions to several strands of literature. First, it adds to the literature on the founding of the Fed and its effect on financial stability. Previous studies have found that the founding of the Fed reduced seasonal liquidity pressures on the banking system (Miron (1986), Mankiw et al. (1987), Bernstein et al. (2010), Carlson and Wheelock (2018)), stabilizing the banking system by reducing financial volatility (measured by nominal interest rates, stock prices, and bank reserves, for instance). We contribute to this literature by showing how the founding of the Fed affected financial stability through the liquidity of the banking system, the risk of contagion and the buildup of systemic pressures.

Second, our paper adds to the literature on shadow banking and central bank liquidity provision. Some scholars have studied the effect of Federal Reserve liquidity provision to non-banks on financial stability during the financial crisis of 2007-2009 (Fleming (2012), Duygan-Bump et al. (2013)). Others have studied the transmission channels of monetary policy in the presence of shadow banking. We contribute to this literature by showing how the provision of public lending facilities interact with the generation and anatomy of a shadow banking system, and their potentially unanticipated effects on systemic risk.

On the theoretical front, we apply a network structure to understand how interlinkeages (both intensively on the degree of borrowing and extensively on the existence and anatomy of links) react to government interventions. There is a recent literature that endogenizes the effects of public interventions to the functioning of banking networks. Erol and Ordoñez (2017), for example, study the interbank network reactions to banking regulations, and show that after a certain threshold liquidity and capital requirements that intend to provide stability to the system may have the unanticipated effect of destroying a network structure that provides 
insurance against financial shocks, which indeed reduces such stability. In this paper we study how lending facilities to certain banks may dismiss the effect on the network functioning and total stability.

\section{Model}

After the Federal Reserve was introduced, non-member banks were not able to access the Fed's discount window. Nevertheless, via their city correspondents in the reserve cities (these are, national member banks), state non-member banks accessed the Fed's discount window indirectly. Our focus in the model is to capture the elasticity of the reserves held in nonmember banks to the indirect access to FED liquidity provision via national member banks. This elasticity is relevant in mapping the results to the modern financial landscape, as several financial intermediaries (mutual funds, investment banks, etc) that are not regulated and not considered banks in the traditional sense, do not have direct access to lending facilities and bailouts, but still their holding of reserves are affected by the indirect access through their participation in financial networks (the so called, shadow banking).

First, to study the effect on the incentives to hold liquidity, e focus on an environment with two banks. Then, to study the anatomy of networks we introduce ore banks and heterogeneity and highlight the nature and direction of contagion.

\subsection{Environment}

The economy is composed by two banks, $x$ (state non-member bank) and $y$ (national member bank in a reserve city). Bank $x$ has $D$ demand deposits and access to a project that pays a net rate of return $r_{x}>0$. Bank $y$ does not have deposits and has a project that pays a net rate of return $r_{y}>0$. Projects can be liquidated in full at any point in time to recover the original investment. Notice that, even geographically, we can think on bank $x$ being in the periphery and bank $y$ in the core (reserve city).

Reserves and investments. After investment into projects, depositors of $x$ may need the funds in advance and withdraw their deposits before the maturity of the projects. Accordingly, $x$ may want to keep reserves to ride these liquidity shocks. We assume bank $x$ is allowed to keep its reserves at bank $y$ and earn net interest $r$ where $r<r_{x}$ and $r<r_{y}{ }^{1}$

\footnotetext{
${ }^{1}$ States used to allow state banks to keep their reserves at reserve cities to account for part of their reserve requirements. Reserve city banks paid $2 \%$ interest on these deposits. It was the case that reserve city banks did not pay more than $2 \%$, which justifies our assumption that $r$ is exogenous.
} 
Accordingly, instead of idling on the reserves, bank $x$ can lend some of its reserves to bank $y{ }^{2}$ Denote $\Phi_{x}$ the cash reserves that $x$ keeps at its vault, and $L$ the amount that $x$ deposits at $y$. Accordingly, $x$ invests $I_{x}=D-\Phi_{x}-L$. Denote $\Phi_{y}$ the cash reserves that $y$ keeps. Then $y$ invests $I_{y}=L-\Phi_{y}$. In the baseline case, our main object of interest are $L$ and $\Phi_{x}$.

Liquidity shocks and profits. The demand for deposits by external depositors is denoted $\zeta \in[0, D]$ where $\zeta$ is drawn randomly from a distribution whose CDF is denoted $S$ and PDF denoted $s$. These are the possible cases:

1. If $\zeta \leq \Phi_{x}$, demanded deposits are paid by $x$ out of the vault cash.

2. If $\zeta>\Phi_{x}$, then cash reserves are not sufficient, in which case $x$ must either liquidate its own project, withdraw its deposits from $y$, or both. These are the possibilities:

(a) If $\Phi_{x}<\zeta \leq \Phi_{x}+L$, deposits at $y$ suffice and $x$ withdraws $L$ from $y .{ }^{3}$ If $y$ does not have sufficient cash, i.e. $\Phi_{y}<L$, then $y$ will have to liquidate its project. Regardless, $x$ can recover $L$ from $y$ on demand. ${ }^{4}$

(b) If $\Phi_{x}+L<\zeta \leq \Phi_{x}+I_{x}$, then $x$ liquidates its own project and recovers $I_{x}$, which, together with $\Phi_{x}$, suffices to ride the shock. In this case, $x$ can keep its deposits at $y$.

(c) If $\Phi_{x}+I_{x}<\zeta$, neither $I_{x}$ from the liquidation of the project, nor deposits $L$ at $y$ suffice by themselves, hence $x$ liquidates its project and withdraws its deposits from $y$, making no profit.

Summarizing these cases, the ex-post profit of bank $x$ is

$$
\pi_{x}= \begin{cases}I_{x} r_{x}+L r & \text { if } \zeta \leq \Phi_{x} \\ I_{x} r_{x} & \text { if } \Phi_{x}<\zeta \leq \Phi_{x}+L \\ L r & \text { if } \Phi_{x}+L<\zeta \leq \Phi_{x}+I_{x} \\ 0 & \text { o.w. }\end{cases}
$$

From an ex-ante perspective, the profits of bank $x$ is,

\footnotetext{
${ }^{2}$ We do not allow $x$ to borrow from $y$ at the investment stage. Indeed, long term borrowing by country banks was stigmatized and seen as weakness.

${ }^{3}$ In principle, $x$ could instead liquidate its own project before withdrawing its deposits from $y$. This never happens in equilibrium due to $r_{x}>r$.

${ }^{4}$ We assume that $r$ is promised by $y$ only if $x$ keeps its deposits at $y$ until the maturity of the project. Accordingly, if $x$ needs to withdraw some of its deposits, it loses the claim to $r$. For simplicity, we assume that $x$ withdraws all of $L$ in this case. We could also assume that $x$ withdraws only as needed and nothing fundamental changes. See Section 2.3.1 for a detailed analysis wherein we analyze this more general case.
} 


$$
\Pi_{x}\left[L, \Phi_{x}\right]=S\left[\Phi_{x}+L\right]\left(I_{x} r_{x}\right)+\Delta\left[\Phi_{x}, L\right](L r)
$$

where $\Delta\left[\Phi_{x}, L\right]=S\left(\Phi_{x}\right)+\left(S[D-L]-S\left[\Phi_{x}+L\right]\right)^{+}$with $z^{+}=\max \{0, z\}$. Note that $S\left(\Phi_{x}\right) \leq \Delta\left[\Phi_{x}, L\right] \leq 1$ and $\Delta\left[\Phi_{x}, L\right]$ are decreasing in $L$. Note also that the expected profit of $x$ does not depend $\Phi_{y}$ because $x$ can always withdraw its deposits on demand, which may be at the expense of the project of $y$.

From the previous discussion, if $\zeta \leq \Phi_{x}$, the shock to bank $x$ does not propagate to bank $y$. If $\Phi_{x}<\zeta \leq \Phi_{x}+L, x$ withdraws $L$ from $y$ which enforces the liquidation of $y$ 's project. If $\Phi_{x}+L<\zeta \leq \Phi_{x}+I_{x}, x$ liquidates its own project and the shock does not propagate to $y$. If $\zeta>\Phi_{x}+I_{x}$, both projects get liquidated. Then the ex-post profit of $y$ is,

$$
\pi_{y}= \begin{cases}I_{y} r_{y}-L r & \text { if } \zeta \leq \Phi_{x} \\ 0 & \text { if } \Phi_{x}<\zeta \leq \Phi_{x}+L \\ I_{y} r_{y}-L r & \text { if } \Phi_{x}+L<\zeta \leq \Phi_{x}+I_{x} \\ 0 & \text { o.w. }\end{cases}
$$

while the ex-ante profit of bank $y$ is,

$$
\Pi_{y}\left[L, \Phi_{x}, \Phi_{y}\right]=\Delta\left[\Phi_{x}, L\right]\left(I_{y} r_{y}-L r\right) .
$$

Timing and optimality. Given the expected profits, bank $x$ chooses $L$ to lend to $y$ and its cash reserves $\Phi_{x}$. We assume that $x$ makes a tioli offer $L$ to $y$, which is always accepted because $y$ 's outside option is 0 . After this offer, bank $y$ chooses its (cash) reserves $\Phi_{y}$. Then banks invest and liquidity shocks materialize in that order.

Bank $y$ chooses $\Phi_{y}$ to maximize $\Pi_{y}$ in (4). Since $\Pi_{y}$ is decreasing in $\Phi_{y}$, optimally, $\Phi_{y}=0$. Bank $x$ chooses $\Phi_{x}$ and $L$ to maximize $\Pi_{x}$ in (2).

Contagion and surplus. Consider a realized shock $\zeta$. If $\zeta \leq \Phi_{x}$, there is no spillover from $x$ to $y$. If $\Phi_{x}+L<\zeta \leq \Phi_{x}+I_{x}, x$ liquidates it own project. In these two cases, there is no contagion from $x$ to $y$.

If $\Phi_{x}<\zeta \leq L+\Phi_{x}$, then $x$ withdraws its deposits $L$. $x$ 's project matures but $y$ 's project gets liquidated. If $L+\Phi_{x}, I_{x}+\Phi_{x}<\zeta$, then both projects get liquidated. In these two cases, $y$ 's project gets liquidated. We call this case upstream contagion from $x$ to $y$. The probability of upstream contagion is then $1-\Delta\left[\Phi_{x}, L\right]$.

Parametric specifications. In order to have some closed form results, we assume that $\zeta$ is drawn from a truncated uniform distribution. For some $\alpha \in[0,1]$, there is $1-\alpha$ probability 
that there is no liquidity withdrawal and $\zeta=0$. There is $\alpha$ probability that $\zeta$ is drawn from $U[0, D]$. Denote $z^{ \pm}=\max \{0, \min \{1, z\}\}$.

$$
\begin{aligned}
\Delta\left[\Phi_{x}, L\right] & =S\left(\Phi_{x}\right)+\left(S\left(\Phi_{x}+I_{x}\right)-S\left(\Phi_{x}+L\right)\right)^{+}=(1-2 \alpha L / D)^{ \pm}, \\
S\left[\Phi_{x}+L\right] & =\left(1-\alpha I_{x} / D\right)^{ \pm}, \\
\Pi_{x}\left[L, \Phi_{x}\right] & =\left(1-\alpha I_{x} / D\right)^{ \pm} I_{x} r_{x}+(1-2 \alpha L / D)^{ \pm} L r .
\end{aligned}
$$

Bank $x$ maximizes $\Pi_{x}$ subject to $I_{x}+L \leq D$. Some simple algebra shows that the optima is given by the three components of bank $x$ 's assets: investment (this is, $I_{x}$ ), deposits in $y$ (this is, $L$, which is also $y$ 's investment) and cash reserves (this is, $\Phi_{x}$ ).

1. If $\alpha \geq \frac{3}{4}$

$$
I_{x}=\frac{D}{2 \alpha}, \quad L=\frac{D}{4 \alpha}, \quad \Phi_{x}=D\left(1-\frac{3}{4 \alpha}\right) .
$$

2. If $\frac{3}{4} \geq \alpha \geq \frac{r_{x}-r}{2 r_{x}}$, then

$$
I_{x}=D \frac{4 \alpha r+r_{x}-r}{\alpha\left(2 r_{x}+4 r\right)}, \quad L=D \frac{2 \alpha r_{x}-r_{x}+r}{\alpha\left(2 r_{x}+4 r\right)}, \quad \Phi_{x}=0
$$

3. If $\frac{r_{x}-r}{2 r_{x}}>\alpha$, then

$$
I_{x}=D, \quad L=0, \quad \Phi_{x}=0
$$

Notice that the sum of the asset's components has to be equal to liabilities $D$.

These three cases are instructive to the pecking order. While $y$ 's investment $L$ is protected only by $x$ 's cash reserves $\Phi_{x}, x$ 's investment $I_{x}$ is protected by both cash reserves and interbank reserves $\Phi_{x}+L$. Even though $y$ 's investments generate more returns, the fact that there are more reserves protecting $I_{x}$ induces more investment in $I_{x}$.

As $\alpha$ gets smaller and there is less risk, reserves fall, starting with reducing cash reserves and following with interbank reserves.

\subsection{Introducing a FED}

Suppose that there is now a FED that provides short term liquidity to $y$, for a maximum amount $m \leq D$, which we refer to as public liquidity provision ( $m=0$ is the baseline case of no liquidity provision in the previous analysis). Our insight is that, although not a member of the FED, $x$ can indirectly access the FED liquidity facility though its interbank relation 
with $y$. We are interested in the impact of indirect access to FED on the reserves of $x$, on contagion and on systemic risks.

Notice that, regardless of the maximum size of the intervention $m, y$ does not keep any reserves and $I_{y}=L$. For $x$, using idle reserves $\Phi_{x}$ or borrowing at most $m$ from the FED via $y$ are substitutes. Any shock $\zeta$ below $m$ can be met at no cost by banks. In contrast, a shock above $m$ will require banks' own reserves or liquidation of projects. Therefore, from the viewpoint of the bank $x$ at the time of deciding its reserves, future shocks effectively are $\zeta^{\prime}=(\zeta-m)^{+}$in so far as liquidation is necessary. $\zeta^{\prime}$ is 0 with probability $1-\alpha+\alpha \frac{m}{D}$ and it is drawn from $U[0, D-m]$ with probability $\alpha \frac{D-m}{D}$. Then,

$$
\begin{aligned}
\Delta\left[\Phi_{x}, L ; m\right] & =S\left(\Phi_{x}+m\right)+\left(S\left(\Phi_{x}+I_{x}+m\right)-S\left(\Phi_{x}+L+m\right)\right)^{+}=(1+\alpha(m-2 L) / D)^{ \pm}, \\
S\left[\Phi_{x}+L ; m\right] & =\left(1+\alpha\left(m-I_{x}\right)\right)^{ \pm}
\end{aligned}
$$

This implies that the ex-ante profit for bank $x$ is

$$
\Pi_{x}\left[L, \Phi_{x} ; m\right]=\left(1+\alpha\left(m-I_{x}\right)\right)^{ \pm}\left(I_{x} r_{x}\right)+(1+\alpha(m-2 L) / D)^{ \pm}(L r) .
$$

And optimal quantities are given by

1. For $\frac{m}{D}+\frac{1}{\alpha} \leq \frac{4}{3}$

$$
I_{x}=D / 2 \alpha+m / 2, \quad L=D / 4 \alpha+m / 4, \quad \Phi_{x}=D(1-3 / 4 \alpha)-3 m / 4 .
$$

2. For $\frac{4}{3}<\frac{m}{D}+\frac{1}{\alpha} \leq \frac{2 r_{x}}{r_{x}-r}$

$$
I_{x}=D \frac{4 \alpha r+r_{x}-r}{\alpha\left(2 r_{x}+4 r\right)}+m \frac{r_{x}-r}{2 r_{x}+4 r}, \quad L=D \frac{2 \alpha r_{x}-r_{x}+r}{\alpha\left(2 r_{x}+4 r\right)}-m \frac{r_{x}-r}{2 r_{x}+4 r}, \quad \Phi_{x}=0
$$

3. For $\frac{2 r_{x}}{r_{x}-r}<\frac{m}{D}+\frac{1}{\alpha}$,

$$
I_{x}=D, \quad L=0, \quad \Phi_{x}=0 .
$$

Notice that the interbank deposit $L$ is more than just an interbank reserve for $x$. $L$ is also an investment and as such increases with FED liquidity provision. Investments in both banks, $I_{x}$ and $L$ increase with $m$ in the same way as both are treated as investments. This leads to a reduction in cash reserves. Moreover, the reduction in cash reserves is more elastic that the increase in investments, and then total reserves $L+\Phi_{x}$ also decrease. 
Figure ?? shows how bank $x$ 's asset components change with public liquidity provision $m$, summarizing the expressions above graphically. For small $m$, bank $x$ increases both own investments $I_{x}$ and the indirect investments through interbank deposits $L$, reducing its cash reserves more elastically than its investments. Compared to the baseline, for medium $m$, idle cash reserves $\Phi_{x}$ are not necessary to protect the investment $L$ as there are enough public funds to do so. Then bank $x$ increases its high return investment $I_{x}$ and reduces its interbank reserve $L$ as those reserves are less needed to protect own investments. For high enough $m$, no reserves are necessary at all and bank $x$ shifts all of its deposits to its high return investment $I_{x}$ and chooses not to have any reserve, in cash or in interbank deposit. These are shown in Figure ??.

Notice that this simple analysis highlights the effect of public liquidity provision on investments and private reserves of shadow banks. Compared to the case without public provision of liquidity $(m=0)$, shadow banks always invest more in illiquid assets and hold less cash reserves. The effect on interbank deposits, however, is not monotonic and depends on the level of intervention. When the FED is very generous it may end up drying up interbank relations, but increasing it when it is not so generous. This last point will indeed have implications for the level of interconnectedness and exposure in the banking system.

Systemic risk. There are two ways we can think of the susceptibility of the system to shocks in the presence of the Fed's liquidity provision. First, realized liquidations, this is we can directly compare the actual probability that there are liquidations not taking into the account the frequency at which FED intervenes and provide liquidity to the system. More formally, the susceptibility of $y$ 's project to shocks (upstream contagion) is $1-\Delta\left[\Phi_{x}, L ; m\right]$, and the susceptibility of $x$ 's project to shocks is $1-S\left(\Phi_{x}+L ; m\right)$ where $L$ and $\Phi_{x}$ are given by $(9),(10)$, and (11).

Second, expected liquidations, this is we can compare the probability that there are liquidations in the absence of FED and the probability that there are realized liquidations or prevented liquidations with FED liquidity provision. More formally, the susceptibility of $y$ 's project to shocks (upstream contagion) is $1-\Delta\left[\Phi_{x}, L\right]$, and the susceptibility $x$ 's project to shocks is $1-S\left(\Phi_{x}+L\right)$ where $L$ and $\Phi_{x}$ are given by (9), (10), and (11) rather than (5), (6), and (7).

1. For $\frac{m}{D}+\frac{1}{\alpha} \leq \frac{4}{3}$,

$$
\begin{gathered}
\Delta\left[\Phi_{x}, L ; m\right]=S\left(\Phi_{x}+L ; m\right)=1 / 2+\alpha m / 2 D, \\
\Delta\left[\Phi_{x}, L\right]=S\left(\Phi_{x}+L\right)=1 / 2-\alpha m / 2 D .
\end{gathered}
$$


Note that these have the same probability but they are not the same events. From the first point of view, susceptibility goes down. From the second point of view, susceptibility goes up. Susceptibility of $y$ 's project goes up because the exposure $L$ is goes up. Susceptibility of $x$ 's project goes up because the total reserves of $x, \Phi_{x}+L$, goes down.

2. For $\frac{4}{3} \leq \frac{m}{D}+\frac{1}{\alpha} \leq \frac{2 r_{x}}{r_{x}-r}$

$$
\begin{gathered}
\Delta\left[\Phi_{x}, L ; m\right]=\frac{2(1-\alpha) r_{x}+r}{r_{x}+2 r}+\frac{\alpha m}{D} \frac{2 r_{x}+r}{r_{x}+2 r}, \\
S\left(\Phi_{x}+L ; m\right)=\frac{r_{x}+4(1-\alpha) r+r}{\left(2 r_{x}+4 r\right)}+\frac{\alpha m}{D} \frac{r_{x}+5 r}{2 r_{x}+4 r}, \\
\Delta\left[\Phi_{x}, L\right]=\frac{2(1-\alpha) r_{x}+r}{r_{x}+2 r}+\frac{\alpha m}{D} \frac{r_{x}-r}{r_{x}+2 r} \\
S\left(\Phi_{x}+L\right)=\frac{r_{x}+4(1-\alpha) r+r}{\left(2 r_{x}+4 r\right)}-\frac{\alpha m}{D} \frac{r_{x}-r}{2 r_{x}+4 r} .
\end{gathered}
$$

From the first point of view, susceptibility goes down. From the second point of view, susceptibility of $y$ 's project (contagion) goes down but susceptibility of $x$ 's project goes up. Susceptibility of $y$ 's project goes down because the exposure $L$ goes down. Susceptibility of $x$ 's project goes up because the total reserves of $x, \Phi_{x}+L$, goes down.

3. For $\frac{2 r_{x}}{r_{x}-r}<\frac{m}{D}+\frac{1}{\alpha}$,

$$
\begin{gathered}
\Delta\left[\Phi_{x}, L ; m\right]=1, \quad S\left(\Phi_{x}+L ; m\right)=1-\alpha+\alpha m / D \\
\Delta\left[\Phi_{x}, L\right]=1, \quad S\left(\Phi_{x}+L\right)=1-\alpha
\end{gathered}
$$

The main implication form this analysis is that the public provision of liquidity indeed increases the susceptibility of the system to liquidation as banks privately choose to hold less reserves, and non-member bank generate an upstream contagion more likely that the FED has to intervene to cover so to avoid the inefficient liquidation of the project.

\subsection{Networks and Contagion}

Now we shift our attention from the pure effects that arise from bank $x$ holding less cash reserves to contagion through the network anatomy. We study multiple pairs of banks and various network structures. Consider now four banks (the less number of banks that we need 
to capture the different directions of contagion) and two pairs. Banks $x_{1}$ and $y_{1}$ are linked as in the baseline, and the same is true for banks $x_{2}$ and $y_{2}$. We assume that banks $x_{1}$ and $x_{2}$ each have their own depositors and projects whereas banks $y_{1}$ and $y_{2}$ each have their own projects. We call $\left\{x_{1}, x_{2}\right\}$ the periphery and $\left\{y_{1}, y_{2}\right\}$ the core.

This extension, however, is more than a simple duplication of the baseline model with two banks. In such benchmark, bank $y$ does not have any incentives to keep reserves, partly because bank $x$ withdraws all of its deposits from $y$ when in needs of any cash and partly because we did not introduce reserve requirements. We generalize these restrictions here and allow that banks $x$ withdraw only as much as they need to meet their liquidity shock. Under this specification, each bank $y$ has incentives to keep reserves, which will be important for coinsurance inside the core between banks $y_{1}$ and $y_{2}$. Moreover, we also introduce reserve requirements in this extended setting.

After introducing these generalizations, we consider two analyses. First, in Section 2.3.2, we study liquidity coinsurance between $y_{1}$ and $y_{2}$. This can be thought of as a clearinghouse. The excess reserves of $y_{1}$ and $y_{2}$ are shared yet their liabilities are not combined. Second, in Section 2.3.3, we study a case in which $y_{1}$ and $y_{2}$ are merged into a single bank $y$ so that their liabilities are also combined as well as their excess reserves.

\subsubsection{Extended setting with two pairs of two banks}

We consider two identical pairs of two banks. We first describe the operation of each pair in the extended setting. Now we assume that $x_{i}$ withdraws only as needed and that $y_{i}$ is subject to reserve requirements $\phi$ meaning that $\Phi_{y_{i}} \geq \phi L_{i}$ is a constraint that $y_{i}$ faces, most likely justified by restricting incentives for risk taking of $y_{i}$ given the access to public liquidity. We assume as a normalization that banks $x_{i}$ do not face any reserve requirement, one of the clearest characteristic in the definition of shadow banking.

Under this new modeling specification, for $m=0, \Pi_{x_{i}}$ is the same as (2). Accordingly, $\Phi_{x_{i}}$ and $L_{i}$ are as given in (5), (6), and (7). For $m \geq 0, \Pi_{x_{i}}$ is the same as (8). Accordingly, $\Phi_{x_{i}}$ and $L_{i}$ are as given in (9), (10), and (11). Now that $y_{i}$ has a chance of meeting withdrawals by $x_{i}, y_{i}$ has incentives to keep reserves. This is reflected in bank $y_{i}$ 's ex-post profit: 


$$
\pi_{y_{i}}= \begin{cases}I_{y_{i}} r_{y}-L_{i} r & \text { if } \zeta_{i}-m \leq \Phi_{x_{i}} \\ I_{y_{i}} r_{y} & \text { if } \Phi_{x_{i}}<\zeta_{i}-m \leq \Phi_{x_{i}}+\Phi_{y_{i}} \\ 0 & \text { if } \Phi_{x_{i}}+\Phi_{y_{i}}<\zeta_{i}-m \leq \Phi_{x_{i}}+L_{i} \\ I_{y_{i}} r_{y}-L_{i} r & \text { if } \Phi_{x_{i}}+L<\zeta_{i}-m \leq \Phi_{x_{i}}+I_{x_{i}} \\ I_{y_{i}} r_{y} & \text { if } \Phi_{x_{i}}+I_{x_{i}}<\zeta_{i}-m \leq \Phi_{x_{i}}+I_{x_{i}}+\Phi_{y_{i}} \\ 0 & \text { if } \Phi_{x_{i}}+I_{x_{i}}+\Phi_{y_{i}}<\zeta_{i}-m\end{cases}
$$

Then the bank $y$ 's ex-ante profit is

$$
\begin{aligned}
\Pi_{y_{i}}\left[L, \Phi_{x_{i}}, \Phi_{y_{i}} ; m\right]= & \Delta\left[\Phi_{x_{i}}, L ; m\right]\left(I_{y_{i}} r_{y}-L_{i} r\right)+\left(S\left(\Phi_{x_{i}}+I_{x_{i}}+\Phi_{y_{i}}+m\right)\right) I_{y_{i}} r_{y} \\
& +\left(-S\left(\Phi_{x_{i}}+I_{x_{i}}+m\right)+S\left(\Phi_{x_{i}}+\Phi_{y_{i}}+m\right)-S\left(\Phi_{x_{i}}+m\right)\right) I_{y_{i}} r_{y} \\
= & \left(1+\alpha\left(m-2 I_{y_{i}}\right) / D\right) I_{y_{i}} r_{y}-\Delta\left[\Phi_{x_{i}}, L_{i} ; m\right] L_{i} r .
\end{aligned}
$$

Accordingly, the unconstrained optimum is given by

$$
I_{y_{i}}=\min \{D / 4 \alpha+m / 4, L\}
$$

1. For $\frac{m}{D}+\frac{1}{\alpha} \leq \frac{4}{3}$, we know from (9) that $L_{i}=D \frac{1}{4 \alpha}+\frac{m}{4}$. Then $I_{y_{i}}=L_{i}=D \frac{1}{4 \alpha}+\frac{m}{4}$ and $\Phi_{y_{i}}=0$.

2. For $\frac{4}{3}<\frac{m}{D}+\frac{1}{\alpha} \leq \frac{2 r_{x}}{r_{x}-r}$, we know from (10) that

$$
L_{i}=D \frac{2 \alpha r_{x}-\left(r_{x}-r\right)}{2\left(r_{x}+2 r\right) \alpha}-m \frac{\left(r_{x}-r\right)}{2\left(r_{x}+2 r\right)} .
$$

This is less than $\frac{D}{4 \alpha}+\frac{m}{4}$. Thence $I_{y_{i}}=L_{i}$ and $\Phi_{y}=0$.

3. For $\frac{2 r_{x}}{r_{x}-r}<\frac{m}{D}+\frac{1}{\alpha}$, we know from (11) that $L_{i}=0$. Then trivially $I_{y_{i}}=L_{i}=0$ and $\Phi_{y_{i}}=0$.

For all cases in $(9),(10)$, and $(11), \Phi_{y_{i}}=0$. Bank $y$ 's incentives to keep reserves are not strong enough, even for $m=0$. Accordingly, reserve requirements bind and $\Phi_{y_{i}}=\phi L_{i}$. This is how one pair would operate in isolation.

Nevertheless, the core banks $y_{1}$ and $y_{2}$ each have access to FED discount lending, which is capped at $m$ in total. We assume that the shocks that $x_{1}$ and $x_{2}$ face are negatively correlated in order to rule out competition for FED funds. There is $\alpha \leq 0.5$ probability $\zeta_{1}$ is drawn 
from $U[0, D]$ and $\zeta_{2}=0$. There is $\alpha \leq 0.5$ probability $\zeta_{2}$ is drawn from $U[0, D]$ and $\zeta_{1}=0$. There is $1-2 \alpha$ probability that $\zeta_{1}=\zeta_{2}=0$. This way, only one bank needs liquidity and we do not need to model FED's priorities over banks. This economy of four banks constitute the network benchmark. Then, when the two pairs operate disjointly under such shocks, the analysis replicates these results above for $\alpha \leq 0.5$.

\subsubsection{Liquidity coinsurance in the network}

Suppose that the core banks $y_{1}$ and $y_{2}$ have a liquidity coinsurance link that does not merge the liabilities but allows for sharing excess reserves.

From the viewpoint of the periphery $x_{1}$ and $x_{2}$, there is no change and the solution is given by (10). From the viewpoint of the core, there are even weaker incentives to keep reserves since banks can free ride on each others' reserves. Accordingly, unconstrained optima are still 0 reserves and reserve requirements bind.

Now, $y_{i}$ can also borrow the reserves of $y_{j}$ when it is hit by a shock. The probability that $y_{i}$ 's project is liquidated is

$$
\begin{aligned}
& \left(1-S\left[\Phi_{x_{i}}+I_{x_{i}}+\Phi_{y_{i}}+\Phi_{y_{j}}+m\right]\right)^{+}+\left(S\left(\Phi_{x_{i}}+L_{i}+m\right)-S\left(\Phi_{x_{i}}+\Phi_{y_{i}}+\Phi_{y_{j}}+m\right)\right)^{+} \\
= & \alpha\left(1-\frac{\overbrace{2 \phi L}^{\text {liquidity coinsurance }}}{D}+2 \phi L+m\right. \\
& =.
\end{aligned}
$$

The probability of upstream contagion is twice this probability. Surplus is then given by

$W[m]=\left(1-\alpha+\alpha \frac{\overbrace{2 \phi L}^{\text {liquidity coinsurance }}+2 \phi L+m}{D}\right) 2 L(1-\phi) r_{y}+\left(1-\alpha+\alpha \frac{L+m}{D}\right) 2(D-L) r_{x}$

where $L$ is given by (10). Compared to surplus in the network benchmark, liquidity coinsurance adds the term $2 \phi L$.

The main result from this extension is that liquidity coinsurance among banks in the core mitigates contagion and improves surplus. 


\subsubsection{Upstream and downstream contagion through the network}

Now suppose that core banks $y_{1}$ and $y_{2}$ are entirely merged into one bank $y$ (they form a single bank holding company or they operate through a frictionless central counterparty). This leads to the merging of reserves as well as the liabilities of the core to the periphery, which leads to the possibility of downstream contagion.

If bank $x_{1}$ withdraws a large amount from the joint bank $y$ that leads to the liquidation of the project of $y, x_{2}$ also loses its promised return $L_{2} r$. This impacts the incentives of the periphery. If $x_{i}$ gets a shock, $\pi_{x_{i}}$ is the same with the baseline. If $x_{j}$ gets a shock and $\zeta_{j}>\Phi_{x_{j}}+\phi\left(L_{i}+L_{j}\right)+m$, then the project of $y$ gets liquidated and $x_{i}$ loses $L_{i} r$. Note that the risk of downstream contagion reduces the expected value of the interbank deposits. Hence, the incentives to keep cash reserves is reduced. Accordingly, optimally $\Phi_{x_{i}}=\Phi_{x_{j}}=0$ and $L_{i}+I_{x_{i}}=D$. Therefore,

$$
\Pi_{x_{i}}=\underbrace{\alpha\left(\frac{L_{i}+m}{D} I_{x_{i}} r_{x}+\frac{I_{x_{i}}-L_{i}+m}{D} L_{i} r\right)}_{x_{i} \text { shocked }}+\underbrace{(1-\alpha)\left(I_{x_{i}} r_{x}+L_{i} r\right)}_{x_{i} \text { not shocked }}-\underbrace{\alpha\left(1-\frac{\phi\left(L_{i}+L_{j}\right)+m}{D}\right) L_{i} r}_{\text {contagion from } x_{j}^{\prime} \text { s shock }}
$$

Then the best response of $x_{i}$ to $x_{j}$ is

$$
L_{i}=\frac{\left(2 \alpha r-\left(r_{x}-r\right)\right) D-\left(r_{x}-r\right) \alpha m-\overbrace{\alpha r\left(D-m-\phi L_{j}\right)}^{\text {downstream contagion }}}{\alpha(2 r_{x}+4 r \underbrace{-2 \phi r}_{\text {reserve pooling }})} .
$$

The Nash equilibrium quantities are

$$
L_{i}=L_{j}=L=\frac{\left(2 \alpha r-\left(r_{x}-r\right)\right) D-\left(r_{x}-r\right) \alpha m-\overbrace{\alpha r(D-m)}^{\text {downstream contagion }}}{\alpha(2 r_{x}+4 r \underbrace{-3 \phi r}_{\text {reserve pooling }})}
$$

The difference with (10) is twofolds. First, the possibility of downstream contagion reduces the investment value of the interbank deposits, which reduces $L$. This is reflected in the term $\operatorname{\alpha r}(D-m)$ in the nominator. Yet, downstream contagion is being mitigated by the fact that there are reserve requirements in place. This is being reflected in the term $3 \phi r$ in the denominator.

Then the probability that $y$ 's project gets liquidated (upstream and downstream contagion) is given by 


$$
2 \alpha(1-(4 \phi L+m) / D)
$$

Expected surplus is given by

$$
W[m]=(1 \underbrace{-2 \alpha+2 \alpha}_{\text {combined liability }} \frac{4 \phi L+m}{D}) 2 L(1-\phi) r_{y}+\left(1-\alpha+\alpha \frac{L+m}{D}\right) 2(D-L) r_{x}
$$

Now that all interbank deposits are being invested by one core bank which is liable to both periphery banks, there is the risk that not half, but all of the potential surplus is lost due to a shock. This combined liability effect is reflected in the terms $2 \alpha$ which were $\alpha$ in (13).

The result of making the core a single bank compared to two co-insured core banks is it introduces downstream contagion and reduces interbank lending. This result is relevant as it shows the importance of the network anatomy to shape the possibilities of contagion and the aggregate liquidity held in the system.

\subsection{Optimal Provision of Public Liquidity}

The previous positive analysis studies how reserves and investments change given public liquidity provision $m$. Now we take a normative approach and briefly discuss implications for optimal provision of public liquidity.

Denote ex-post surplus from projects $w(m)$ :

$$
w(m)= \begin{cases}I_{x} r_{x}+I_{y} r_{y} & \text { if } \zeta-m \leq \Phi_{x} \\ I_{x} r_{x} & \text { if } \Phi_{x}<\zeta-m \leq \Phi_{x}+L \\ I_{y} r_{y} & \text { if } \Phi_{x}+L<\zeta-m \leq \Phi_{x}+I_{x} \\ 0 & \text { o.w. }\end{cases}
$$

where $I_{x}, L$, and $\Phi_{x}$ are given by (9), (10), and (11). Expected surplus is

$$
\begin{aligned}
& W[m]=S\left[\Phi_{x}+L+m\right] I_{x} r_{x}+\left(S\left(\Phi_{x}+m\right)+S\left(\Phi_{x}+I_{x}+m\right)-S\left(\Phi_{x}+L+m\right)\right) I_{y} r_{y} \\
= & \left(\left(D+\alpha m-\alpha I_{x}\right) I_{x} r_{x}+(D+\alpha m-2 \alpha L) L r_{y}\right) / D
\end{aligned}
$$

For $\frac{m}{D}+\frac{1}{\alpha} \leq \frac{4}{3}, W[m]=\frac{(D+\alpha m)^{2}}{4 \alpha D} r^{\prime}$. For $\frac{2 r_{x}}{r_{x}-r}<\frac{m}{D}+\frac{1}{\alpha}, W[m]=((1-\alpha) D+\alpha m) r_{x}$. Since $W[m]$ is increasing in both regions. As for the middle region $\frac{4}{3}-\frac{1}{\alpha} \leq \frac{m}{D} \leq \frac{1-\beta}{\gamma}-\frac{1}{\alpha}$, the 
qualitative features of $W[\mathrm{~m}]$ is highly case specific and involve very messy algebra. The exact optimal can be easily computed for given parameters, but general qualitative features are difficult to pin down. We provide conditions under which the optimum is interior: it is not optimal to not provide any liquidity $(m \neq 0)$ and not optimal to cover all possible withdrawals $(m \neq D)$.

Condition for $m \in(0, D)$ when $\alpha$ is large: When $\alpha>0.75$, if $r_{y}$ is large compared to $r_{x}$ and $r_{x}$ is large compared to $r$, the optimal $m$ is interior.

Proof: For $\alpha>0.75$ and $m=D\left(\frac{4}{3}-\frac{1}{\alpha}\right)>0$, we have $W[m]=\frac{4 \alpha D}{9} r^{\prime}$. Under $r_{x} \geq 2 r$, $m=D$ falls into the third region. Then in the third region, the optimal is $I_{x}=D$ and $L=0$. Then $W[m]=D r_{x}$. Under $2 \alpha r_{y} \geq(9-4 \alpha) r_{x}, m=D\left(\frac{4}{3}-\frac{1}{\alpha}\right)$ is better so that the optimum is not $m=D .{ }^{5} \mathrm{QED}$.

Intuitively, even though liquidity provision is socially costless, high liquidity provision makes $x$ shift its investment from $L$ to $I_{x}$. $L$ is used at $y$ 's project, which is more productive when $r_{y}$ is sufficiently large compared to $r_{x}$. Thus, high liquidity provision under these conditions creates investment misallocation and reduces welfare.

Condition for $m \in(0, D)$ when $\alpha$ is small: When $\alpha<0.75$, if $r_{x}$ is small compared to $r$, the optimal policy $m$ is interior.

Proof: When $\alpha<0.75$, the first region is ruled out. Comparing the local maxima in the second region with third region has involved algebra. Instead, if we assume that $1<\frac{2 r_{x}}{r_{x}-r}-\frac{1}{\alpha}$, third region is also ruled out and we have only the second region. Then if we show that the right derivative of $W[m]$ at $m=0$ is positive and left derivative of $W[m]$ at $m=D_{x}$ is negative, the solution is interior. Some algebra shows that for $\left[r_{y}>3 r_{x}\right.$ and $\left.r_{x}>4 r\right]$, or for $\left[r_{y}>1.5 r_{x}>>r\right]$, the derivative conditions are satisfied. ${ }^{6}$ QED

Intuitively, when the probability that liquidity is needed is small enough, the Fed still does not want to provide so much liquidity to distort investment, nor so little that induces inefficient liquidations.

\section{Empirical Evidence}

In this section we discuss empirically how the introduction of the Fed's lending facilities change the aggregate liquidity in the system, the intensity of interbank relations and the

\footnotetext{
${ }^{5}$ Note, we can also show that the right derivative of $W[m]$ at $m=D\left(\frac{4}{3}-\frac{1}{\alpha}\right)$ is positive. This means that the optimal is in fact strictly inside the middle region $\frac{4}{3}<\frac{m}{D}+\frac{1}{\alpha}<\frac{2 r_{x}}{r_{x}-r}$.

${ }^{6} \mathrm{~A}$ reasonably tight condition is $r_{x} \frac{\left(r_{x}+r\right)\left(r_{x}+11 r\right)}{2\left(-r_{x}^{2}+3 r r_{x}+r^{2}\right)^{+}}>r_{y}>r_{x} \frac{3\left(5 r_{x}^{2}+2 r r_{x}+r^{2}\right)}{2\left(5 r_{x}^{2}-7 r r_{x}-7 r^{2}\right)^{+}}$
} 
anatomy of interbank networks.

\subsection{The Interbank System Under the Federal Reserve System}

In the 19th century, the U.S. banking system was fragmented due to restrictions on branching. The interbank system was an institutional response to coordinate interregional payment of goods and services. The interconnected nature of the U.S. banking system was solidified after the passage of the National Banking Acts in 1863, which allowed national banks to meet their reserve requirements by keeping interbank deposits in reserve and central reserve cities.

Central reserve city banks were required to hold cash reserves equal to $25 \%$ of their deposits, while Reserve city banks were also required to hold reserves equal to $25 \%$ of their deposits, of which one-half could be deposits with a correspondent bank in a Central reserve city. Lastly, Country banks were required to hold reserves equal to $15 \%$ of their deposits, but they could keep three-fifths of the $15 \%$ as deposits with a correspondent bank in reserve or central reserve cities. State bank regulators passed similar laws afterward.

Contemporaries thought the interbank system contributed to the banking panics during the National Banking Era because it transmitted liquidity crises across banks. In particular, banks in agricultural and other regions faced seasonal demands for cash and credit due to crop planting and harvesting in the spring and fall. The cash demands of the country banks drained cash balances held in New York City banks and led to seasonal peaks in interest rates in the spring and fall. In panics, banks outside financial centers withdrew funds simultaneously, forcing banks in reserve and central reserve cities to suspend payments; this in turn caused banks outside financial centers to suspend when they could not access their interbank deposits.

The Federal Reserve Act of 1913 created the Federal Reserve System with the goal of preventing panics and stabilizing the U.S. banking system. The founders desired to create an elastic currency to smooth out seasonal fluctuations in the demand for currency and credit. To do so, it offered liquidity through the Fed's discount window, the tool to create such higher elasticity of currency to shocks.

The Act made it compulsory for national banks to join but voluntary for state banks. While founders of the Federal Reserve System hoped to bring state banks under a more unified system of regulation and supervision, a small fraction of state banks become members of the Federal Reserve System. By June 1915, only 17 state banks had become Fed members. More state banks joined after the revision in 1917, which lowered capital and reserve requirements. 
Figure 1 shows the state bank membership rate per each state in 1920. Membership grew slowly to a peak of 1,648 state banks (compared with 19,141 nonmember banks) in 1922 .

While member banks tended to be larger than nonmembers, a large percentage of total deposits were held by nonmember banks. In 1923, member banks held less than two-thirds of total U.S. commercial bank deposits ( $\$ 27.1$ billion versus $\$ 10.6$ billion in nonmember banks). This meant that a large fraction of banks operated without explicit public liquidity provision. ${ }^{7}$ We argue that many state banks did not join the Federal Reserve System because they enjoyed the benefits of Federal Reserve liquidity provision through their city correspondents while avoiding the need to comply with stricter regulation.

Before the Fed was established, country banks borrowed short-term funds mainly from their correspondents. After the Fed was established, they continued to rely on their correspondents to borrow for short periods under the understanding that, when city correspondents ran out of funds, they would go to the Fed and rediscount their own eligible paper to replenish their liquidity positions. In other words, country banks were able to indirectly access the benefit of Federal Reserve rediscount facilities through their correspondents.

By December 1929, nonmember banks comprised $65 \%$ of all commercial banks (only $10 \%$ of state banks were members) with a $25 \%$ of total deposit holdings. The lack of direct access to the discount window for nonmember banks made them vulnerable to liquidity crises because their reserve city correspondents could as well deny them short-term liquidity. Between 1921 and 1929 , over $75 \%$ of all bank failures were banks that were not members of the Federal Reserve System. During the Great Depression, the annual average suspension rate among nonmembers was $8 \%$, twice the rate for member banks.

\subsection{Bank Liquidity and the Size of the Interbank System}

\subsubsection{Data Sources}

We use various datasets to examine how the founding of the Federal Reserve changed the structure of the interbank network and affected the stability of the banking system. First, we use state-level balance sheet information for national and state banks from 1910 to 1929, using

\footnotetext{
${ }^{7}$ Even though only member banks were given access to Fed services, including the discount window, the Act made it possible for the Fed to extend the discount window to nonmember banks in special circumstances with the approval of the Federal Reserve Board.. Prior to 1923, for instance, the Board allowed the Reserve Banks to discount for member banks eligible paper acquired from nonmember banks (Hackley, 1973, p. 119). Thereafter, the Board approved the extension of credit to nonmember banks only in exceptional circumstances (Carlson et al., 2010).
} 
data for the last day of June from the Annual report of the Comptroller of the Currency. ${ }^{8}$ Among national banks there were banks classified as country banks, reserve city banks and central reserve city banks. Even though we do not have this classification for state banks, most major banks in reserve and central reserve cities were indeed national banks, and state banks in these cities were small in size and number. Given the lack of direct information about membership in this dataset, we treat national banks as a proxy of member banks and state banks as a proxy of nonmember banks.

We augment this data with bank level information for all state-chartered banks in New York from 1910 to 1929. The New York state banking department conducted inspections of all banks and trust companies with a state charter and published quarterly balance sheets in the Annual Report of the Superintendent of Banks. We collected bank-level balance sheet information for June to match the state-level balance sheet information. Because some states had a relatively large fraction of state member banks, we use this data to verify that statebalance sheet patterns for state banks in these states are not driven by state member banks. In addition, because we compare state banks to country national banks, we use this data to verify that state-level balance sheet information is not driven by state banks in financial centers.

For our analysis in New York, we also use the Annual Report of the Federal Reserve Board to identify state banks that were members of the Feral Reserve System and those that were not. The report provided information on all state member banks for the year by district. Most state member banks joined in 1917 and 1918, and very few new banks joined or left the membership afterwards. We use membership information in 1920 to compare state member banks to state nonmember banks.

\subsubsection{State-Level Balance Sheet Analysis}

By creating a central bank that can provide liquidity during the time when money and credit demand peaked, the Federal Reserve enabled banks to hold less liquid assets. A reduction in reserve requirements for Fed member banks also contributed to a decline in the liquidity of the banking system. As a result, national banks operated with much less liquid assets during the 1920s than they had before the Fed was founded. In the meantime, the presence of the Fed also led to a decline in cash assets for state banks. Table 1 shows the summary statistics provides summary statistics for national and state banks from 1910 to 1929. The period is subdivided for 1910-1914 and 1921-1929.

\footnotetext{
${ }^{8}$ While the report provided national bank balance sheet information at the quarterly frequency, it only provided state bank balance sheet information for June.
} 
We divided the sample period into two periods for two reasons. First, we want to account for the three-year phase-in period for the Fed's member banks to adjust to new reserve requirements under the Federal Reserve System and the impact of World War I financing on the banking system. Second, we cannot use information on state banks' interbank deposits due from other banks because it includes information on deposits due from the Federal Reserve Bank.

Figure 2 plots the share of bank assets held in the form of vault cash for member and nonmember banks from 1910 to 1929. The main point here is that both member and nonmember banks reduced their cash in vault.

Figure 3 shows the evolution of bank deposits in other banks (assets that what we refer to due from). As can be seen both reduced for members and nonmembers.

Almost as a by product of the previous point, Figure 4 shows the evolution of banks' deposits from other banks (liabilities that what we refer to due to). These also reduced for members and nonmembers. The point we want to push with these two figures is that the lowest holding of cash was not compensated by a larger cross-holding of deposits. In this sense, aggregate liquidity did decline.

Despite a reduction in the size of the interbank market measured by deposit holdings, financial city banks remained vulnerable to runs on interbank deposits by nonmember banks. Figure 5 plots the volume of interbank deposits due to other banks (relative to their total assets) just for central reserve and reserve city banks. For reserve city banks, the volume of deposits due to national banks fell by $50 \%$, while the volume of deposits due to state banks fell only by $20 \%$. Similarly, for central reserve city banks, deposits due to national banks fell by $75 \%$ while deposits due to state banks declined by a much smaller amount, almost $20 \%$. While the Fed's founders succeeded in shrinking the size of due-to deposits held in financial centers, financial center banks remained vulnerable to runs because nonmember banks still held a large amount of interbank deposits in financial centers.

These results highlight that the study of how liquidity was held over the network is very relevant to understand contagion and the sources of systemic risk in the financial market.

Even though total liquidity and the interbank deposits declined, the presence of the Fed increased the level of short-term borrowing by banks. In particular, the presence of the Fed increased the short-term lending from city correspondents to nonmember banks. Figure 6 plots the ratio of short-term borrowing to total assets for banks. As noted previously, before the founding of the Fed, country banks often borrowed for short periods from their correspondents, particularly during when local demands for currency and loans were at their 
highest. However, banks borrowed little prior to the establishment of the Fed. Moreover, reserve and central reserve city banks hardly borrowed at all.

After the establishment of the Fed, banks tended to borrow more. Panel A shows short-term borrowing for national banks which relied on the Fed's discount window. The borrowing peaked in 1920 when the Fed offered the preferential discount rates on loans secured by government notes and bonds to support World War I. After the Fed removed the preferential rate and raised its discount rate in 1920-1921, the level of borrowing fell. However, the volume of borrowing was considerably higher during the remainder of the 1920s, than it had been before the funding of the Fed. Notably, financial center banks borrowed heavily during the 1920s, which suggests that they were making short-term loans to nonmember banks.

Panel B shows short-term borrowing for country banks. Country banks also increased shortterm borrowing. While nonmember banks did not have access to the discount window, they also borrowed more after the Fed's founding. However, nonmember banks were not able to borrow as freely as member banks. Before the Fed's founding, the level of borrowing by member and nonmember banks was comparable, averaging 1 percent relative to their total assets. After the Fed's founding, nonmember banks borrowed 2.8 percent, whereas member banks borrowed 3.4 percent.

\subsubsection{Bank-Level Balance Sheet Analysis}

The Federal Reserve System membership was not popular among state banks. States with financial and manufacturing sectors had a higher proportion of state bank membership than agricultural states. Given the irregular geographic distribution of membership, one might be concerned that balance sheet conditions of states with a high proportion of state bank membership are reflecting those of state member banks rather than state nonmember banks. In addition, though small in size and number, data on state banks include state banks in

all three types of reserve cities, so changes in asset ratios may be driven by changes in state banks in financial center banks. To alleviate these concerns we compare the asset portfolios and short-term borrowing of member and nonmember banks that reside outside reserve and central reserve cities from 1910 to 1929. 


\section{References}

Anbil, Sriya and Angela Vossmeyer, "Liquidity from Two Lending Facilities," 2017.

Bernstein, Asaf, Eric Hughson, and Marc D Weidenmier, "Identifying the effects of a lender of last resort on financial markets: Lessons from the founding of the fed," Journal of Financial Economics, 2010, 98 (1), 40-53.

Carlson, Mark A and David C Wheelock, "Furnishing an'Elastic Currency': The Founding of the Fed and the Liquidity of the US Banking System," Federal Reserve Bank of St. Louis Review, 2018, (1), 17-44.

Duygan-Bump, Burcu, Patrick Parkinson, Eric Rosengren, Gustavo A Suarez, and Paul Willen, "How effective were the Federal Reserve emergency liquidity facilities? Evidence from the asset-backed commercial paper money market mutual fund liquidity facility," The Journal of Finance, 2013, 68 (2), 715-737.

Erol, Selman and Guillermo Ordoñez, "Network reactions to banking regulations," Journal of Monetary Economics, 2017, 89, 51-67.

Fleming, Michael J, "Federal reserve liquidity provision during the financial crisis of 20072009," Annu. Rev. Financ. Econ., 2012, 4 (1), 161-177.

Mankiw, N Gregory, Jeffrey A Miron, and David N Weil, "The Adjustment of Expectations to a Change in Regime: A Study of the Founding of the Federal Reserve," The American Economic Review, 1987, 77 (3), 358.

Miron, Jeffrey A, "Financial panics, the seasonality of the nominal interest rate, and the founding of the Fed," The American Economic Review, 1986, 76 (1), 125-140.

Mitchener, Kris James and Gary Richardson, "Network Contagion and Interbank Amplification during the Great Depression," Technical Report, National Bureau of Economic Research 2016. 